\title{
Production value of agricultural land - a factor determining the consolidation of land - case study
}

\author{
Żanna Stręk, ${ }^{*}$ Karol Noga \\ University of Life Sciences in Lublin, Department of Environmental Engineering and Geodesy, Leszczyńskiego 7 20-069 \\ Lublin, Poland; zanna.krol@up.lublin.pl
}

\begin{abstract}
Land as a means of labour and agricultural production is a very important or even the most important good of a farmer. For centuries spatial structure of Polish rural areas was determined by historical and legal, social and economic, political, economic, technical and demographic conditions. A characteristic feature of land is the fact that it is a part of nature used for plant production but at the same time it is not a product of human labour so it cannot be replaced by a different means of production or its area cannot be increased. Soil quality is one of the most important factors determining potential high income from agricultural activity. Agricultural land quality is expressed as soil class and its suitability for cultivating specific plants or groups of plants - as soil and agricultural complexes. Throughout Poland uniform classification of soil was applied taking into account soil morphology and its physical properties. The study contains elaborate descriptive and cartographic material such as classification maps in the scale equivalent to cadastral maps. In studies concerning spatial and economic phenomena occurring in rural land, respective villages are grouped into larger typological units with respect to similarity of their features. The classification was used in developing a method for the appraisal of land for land consolidation and exchange works. The classification according to land uses can be applied in economic practice better by being expressed as a single number in the form of a productivity ratio rather than a soil quality index. This is the premise underlying the purpose of this paper - calculating the ratio of productivity for cropland and grassland for the needs of identifying villages similar in that respect.
\end{abstract}

The studies were carried out in 116 villages in the county of Łęczna in Lublin voivodeship. Data relating to surface of respective classes of soil was retrieved from the land and buildings register and the calculation of the ratio was based on scores assigned on a 100-point scale.

\section{Introduction}

Land as a means of labour and agricultural production is a very important or even the most important good of a farmer. For centuries spatial structure of Polish rural areas was shaped by historical and legal, social and economic, political, economic, technical and demographic conditions [1]. A characteristic feature of land is the fact that it is a part of nature used for plant production but at the same time it is not a product of human labour so it cannot be replaced by a different means of production or its area cannot be increased [2]. Therefore, it is invaluable to farm managers. The value of land depends on the natural conditions, legal and ownership structure, attractiveness of the area as well as on demand and supply [3]. Reference literature mentions a few factors determining the value of cropland. Authors state that the value of land can be determined by potential environmental contamination [4], soil exhaustion and degradation [5], and the cropping history of the plot $[6,7]$.
In addition, it is worth noting that urban development also affects sustainable growth or the utilization of rural areas. The development of cities and infrastructure is often observed in areas with high-quality cropland, which as a consequence leads to irrevocable losses in the productivity of agriculture in the European Union [8, 9]

The European landscape is to a large extent dominated by crops. More than $35 \%$ of all land in the EU has an agricultural use. Thus, the utilization of cropland plays a key role for the potential effect of land use on sustainable development of the environment in Europe. Hence, understanding the spatial dynamics of cropland coverage is of key importance, the more than changes in the use of land are closely connected with multiple economic, social, political and environmental processes. These processes are differentiated in time and space, involving a complex scope of interactions between human factors and the environment [10]. At present - in European countries we can identify agricultural areas that are competitive in many respects (economic, social, business, cultural ones etc.). In addition, in some areas agricultural production run

Corresponding author: zanna.krol@up.lublin.pl 
by private farms owned by individuals is on the verge of or falls below the limit of profitability [11].

Soil quality is one of the most important factors conditioning potential options for deriving high income from agricultural activity [12]. Therefore, it is necessary to monitor changes in the use of land $[13 ; 14]$. Throughout the area of Poland uniform classification of soil was applied taking into account soil morphology and its physical properties. The study contains elaborate descriptive and cartographic material such as classification maps in the scale equivalent to cadastral maps [15]. Agricultural soil quality is expressed as soil class, and its suitability for cultivating specific plants or groups of plants - as soil and agricultural complexes. Detailed studies carried out by Witek and Górski [16] regarding planning the crops of 4 cereals and potatoes in Poland for respective classes of croplands and grasslands, quantified the value of production classes according to 100-point scale. The classification according to uses can be applied in economic practice better by being expressed as a single number in the form of a productivity ratio rather than a soil quality index. The quantified potential quality score of respective classes of cropland is the production value of soil classes. The type of use and soil quality class both affect the value of land in the appraisal process related to land consolidation and exchange works [17-19]. It should be noted that the prepared indicators of usefulness of cropland and grassland are used in the algorithm for identifying groups of features for the needs of hierarchization of land consolidation works in rural areas [20], which at a later stage results in the hierarchization of land consolidation works in rural areas as described in literature [2125].

This is the premise underlying the purpose of this paper - calculating the ratio of productivity of cropland and grassland for the needs of identifying villages that are similar in this respect. The studies were carried out in 116 villages in the county of Łęczna in Lublin voivodeship (Figure 1).

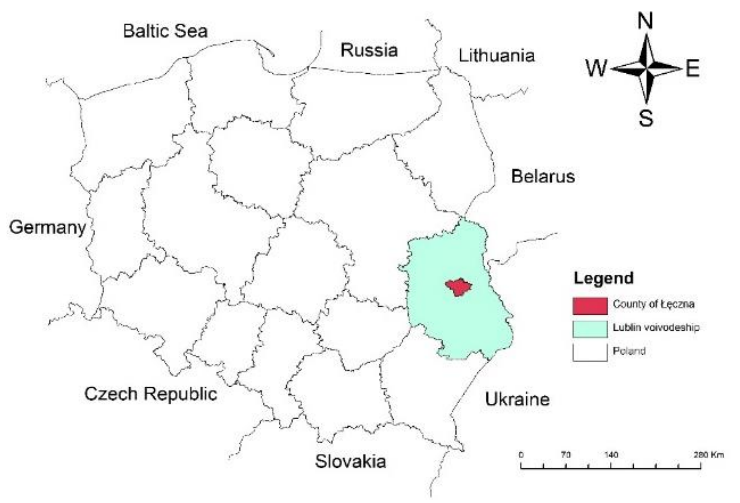

Fig. 1. Map of location of the studied county

\section{Materials and methods}

Detailed calculations were based on the quantified potential quality score of respective classes of cropland, that is, the production value of soil classes [16]. The previous estimates regarding land consolidation and exchange assume the price of 1 ha of the specific class of soil which is then interpolated or extrapolated in a linear manner for other soil classes. In the multiple factor land estimation method, Noga [1] used the study of [16] as the basis for determining the productivity of soil in cropland. Making use of specific points for respective soil classes, their productivity was calculated for cropland, meadows and pastures in 116 villages within the study area. Based on scores calculated for respective classes and agricultural land, productivity indices were determined for cropland -Wg, meadows- Wt, and pastures $\mathrm{Wp}$ according to the formula [3]:

$$
W_{g}=\frac{\sum_{i}^{n}\left(W_{p n k} * P_{n k}\right)}{P_{g}}
$$

where:

$W_{g}$ - index for cropland in the village,

$W_{\text {pnk }}$-unit size of points of soil valuation classes for cropland,

$P_{n k}$ - area of soil valuation classes of cropland,

$\mathrm{P}_{\mathrm{g}}$-total area of cropland in the village,

Analogous values were also calculated for meadows $-\mathrm{W}_{\mathrm{t}}$ and for pastures $\mathrm{W}_{\mathrm{p}}$.

Data relating to surface of respective classes of soil was retrieved from the land and buildings register and the calculation of the ratio was based on scores assigned on a 100-point working scale (Tab. 1).

Table 1. Scores assigned to soil classes for cropland and

\begin{tabular}{|c|c|c|c|}
\hline \multirow{2}{*}{$\begin{array}{c}\text { Soil } \\
\text { class }\end{array}$} & \multirow{2}{*}{ Cropland } & \multicolumn{2}{|c|}{ Grassland } \\
\cline { 3 - 4 } & $\begin{array}{c}\text { Permanent } \\
\text { pastures }\end{array}$ & $\begin{array}{c}\text { Permanent } \\
\text { meadows }\end{array}$ \\
\hline I & 100 & 90 & 90 \\
\hline II & 92 & 80 & 80 \\
\hline IIIa & 83 & 65 & 65 \\
\hline IIIb & 70 & 65 & 65 \\
\hline IVa & 57 & 45 & 4 \\
\hline IVb & 40 & & 28 \\
\hline V & 30 & 28 & 28 \\
\hline
\end{tabular}




\begin{tabular}{|c|c|c|c|} 
VI & 18 & 15 & 15 \\
\hline
\end{tabular}

The quantified potential quality score of respective classes of cropland is the production value of soil classes, which is illustrated in Table 1. In order to illustrate the production value of soil valuation classes for cropland, scores were calculated for each class in the village. Despite the grassland (meadows, pastures) in soil valuation classes has an assigned unit production value per 1 ha expressed as score, this paper calculates them separately.

The calculated productivity scores for cropland, meadows and pastures were subject to detailed analysis and assessment by splitting the analysed area into four groups of villages with regard to soil productivity index, separately for cropland, meadows and pastures, which is illustrated in Table 2. Based on the analysis of conversion ratios, four soil quality ranges were identified: very good $>80$ pts; good $79-60$ pts; poor $59-30$ pts; very poor $<30$. The villages were grouped based on the value of conversion ratios (Tab. 2).

Table 2. Number of villages in separate groups

\begin{tabular}{|c|c|c|c|c|c|}
\hline \multicolumn{2}{|c|}{ Village group } & 1 & 2 & 3 & 4 \\
\hline \multicolumn{2}{|c|}{ Soil quality } & $\begin{array}{l}\text { very } \\
\text { good }>\end{array}$ & $\begin{array}{l}\text { good } \\
79-60\end{array}$ & $\begin{array}{c}\text { poor } 59- \\
30 \text { pts. }\end{array}$ & $\begin{array}{c}\text { very } \\
\text { poor }<30\end{array}$ \\
\hline \multirow{6}{*}{$\begin{array}{c}\text { Numb } \\
\text { er of } \\
\text { village } \\
\text { s in } \\
\text { the } \\
\text { group } \\
\text { for: }\end{array}$} & $\begin{array}{l}\text { Croplan } \\
\text { d } \\
\text { producti } \\
\text { vity } \\
\text { index }\end{array}$ & 8 & 38 & 62 & 8 \\
\hline & $\%$ & 6.9 & 32.8 & 53.4 & 6.9 \\
\hline & $\begin{array}{c}\text { Pastures } \\
\text { producti } \\
\text { vity } \\
\text { index }\end{array}$ & 0 & 1 & 97 & 16 \\
\hline & $\%$ & 0 & 0.9 & 83.6 & 13.8 \\
\hline & $\begin{array}{l}\text { Meadow } \\
\text { s } \\
\text { producti } \\
\text { vity } \\
\text { index }\end{array}$ & 0 & 1 & 100 & 12 \\
\hline & $\%$ & 0 & 0.9 & 86.2 & 10.3 \\
\hline
\end{tabular}

Source: own study

Considering the outcome of studies presented in Table 2, it can be stated that the county of Łęczna is dominated by poor-quality soil. The largest number of villages in terms of the productivity index of cropland as well as of meadows and pastures was found in village group no. 3 . With regard to cropland, as many as 62 villages were included in the group with poor-quality soils, which corresponds to $53.4 \%$ of all villages in the county. However, in terms of pastures it was 97 villages, which corresponds to $83.6 \%$ of the total number of villages; poor quality soils in meadows occur in 100 villages of the county of Łęczna, which corresponds to $86.2 \%$. As regards very good soil - only 8 villages in the county have very good quality cropland, which accounts for $6.9 \%$ of all villages. The best soil valuation class for cropland in Poland is class I, but it does not occur in the county of Łęczna. Very good quality soil in pastures and meadows was not recorded in any of the villages in the analysed county. It is noteworthy that there are quite a few villages with good-quality cropland - they are as many as 38 , which accounts for $32.8 \%$. On the other hand, good-quality soil in meadows and pastures was found in one village only. It is also significant that only a small percentage of soils of very poor quality occurred in the county of Łęczna - for cropland in 8 villages, pastures in 16 and meadows in 12 .

\section{Result and discussion}

Based on detailed surveys, Figures No. 2, 3 and 4 were drawn illustrating average spatial differentiation of soil valuation classes in the county of Łęczna. Looking at the productivity index of cropland it is noticeable that villages in the county of Łęczna form clusters of similar productivity. The best soils are mainly situated in the southwestern part of the county. On the other hand, cropland of the poorest production value is situated in the northern part of the county of Łęczna. Individual villages with very poor soils were found in the south of the analysed area. In studies concerning spatial and economic phenomena occurring in rural land, respective villages are grouped into larger typological units with respect to similarity of their features [1]. The classification was used in developing a method for the appraisal of land for the purposes of 
land consolidation and exchange works. Based on studies concerning the ratio of productivity of cropland in the process of land consolidation and exchange, the classification according to uses can be better applied in economic practice by being expressed as a single number in the form of productivity ratio rather than soil quality index.

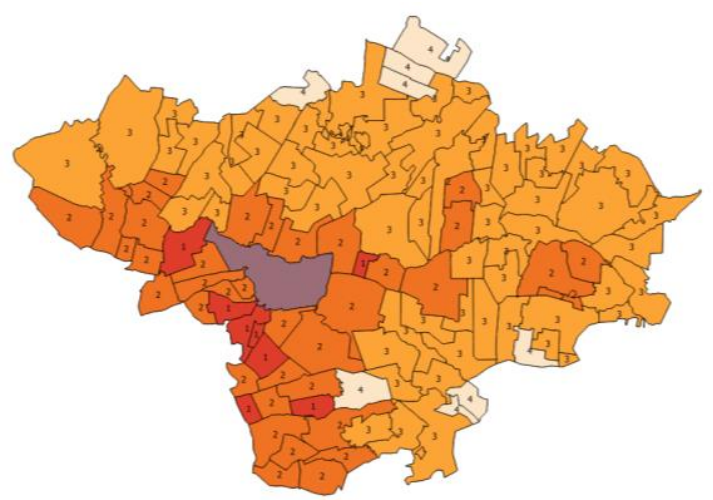

Fig. 2 Spatial division of the county of Łęczna with regard to productivity of cropland

Considering the ratio of productivity of grassland, it is noticeable that villages in the county of Łęczna form clusters of similar productivity but these clusters are less differentiated than in case of cropland. The area of two villages does not include meadows and pastures - these are Ludwików in the commune of Spiczyn and Łuszczów Kolonia in the commune of Łęczna. Detailed analyses showed that soils of very good quality in meadows and pastures did not occur in any of the villages. Good-quality soil was found in the village Brzeziny (pastures) and in the village Stawek (meadows).

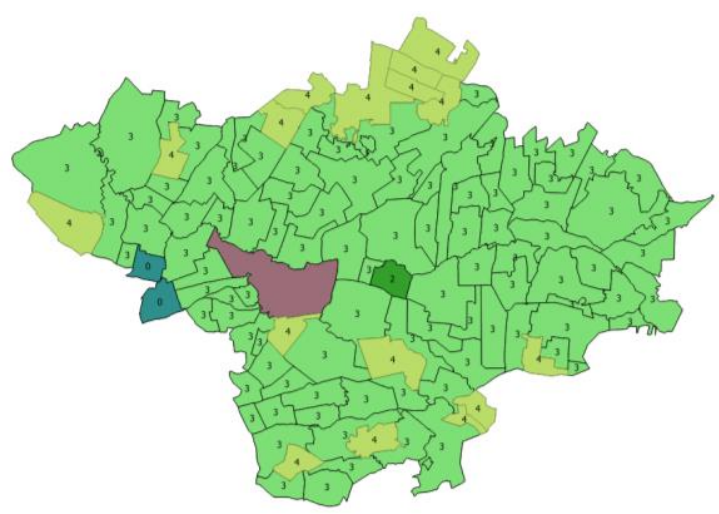

Fig. 3 Spatial division of the county of Łęczna with regard to productivity of pastures

As shown in Figures 2 and 3, most villages in the analysed county have poor-quality soil in meadows and pastures. Soil of very poor quality is found mainly in the northern part of the county of Łęczna. In this region of the county the area of cropland is observed to decrease and that of meadows to increase with regard to the presence of lakes. Lakes are a characteristic element of the county of Łęczna and they stimulate the development of tourism. They are post-glacial or karst lakes. Not all lakes are used for tourism purposes; some of them, with regard to difficult access or their natural values, are used as fisheries or nature reserves.

Despite such environmental conditions, soil regime is not improved. In villages with lakes within their perimeter the quality of soil is poor. For instance, the village Krzczen in the commune of Ludwin has a high share of meadows and ecological areas due to its location by Lake Krzczeń within the perimeter of which peat soils occur. On the other hand, the quality of both cropland and meadows/pastures is classified as group 4, that is, very poor soils.

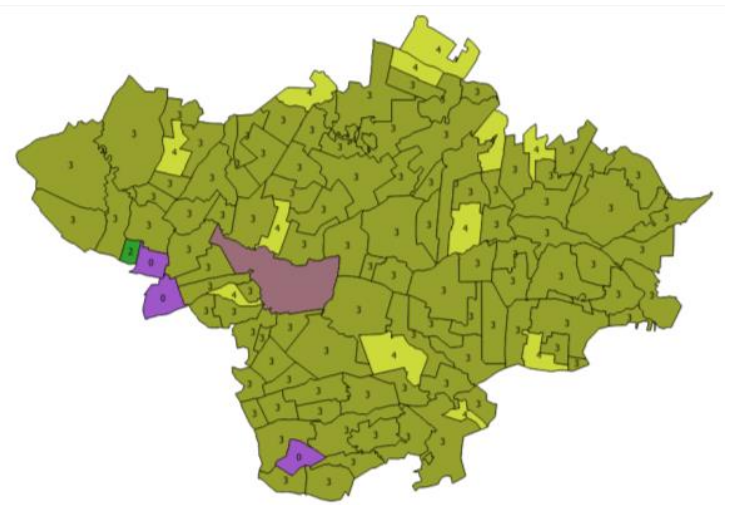

Fig. 4 Spatial division of the county of Łęczna with regard to productivity of meadows

Detailed analyses were carried out for the structure of land use based on data retrieved from the land and buildings register. The total area of a farm is inclusive of all land forming part of the farm, that is, all land used for agricultural purposes (cropland, orchards, meadows and pastures), land used for nonagricultural purposes: forests, courtyards, land under buildings or land for building development, decorative gardens etc. The analysed area, as shown in Table 3, is dominated by agricultural land accounting for as much as $77.0 \%$ of the area of the analysed county and occupying 47542.09 ha. Agricultural land is dominated by cropland 
with the area of $31932.71(51.7 \%)$. On the other hand, grassland accounts for $18.2 \%$ of the area of the county, including: 2351.78 ha of permanent pastures $-3.8 \%$ and 8841.58 ha of permanent meadows $-14.3 \%$.

Table 3. Structure of land use in the county of Łęczna

\begin{tabular}{|c|c|c|c|}
\hline No. & $\begin{array}{c}\text { Type of land in } \\
\text { use }\end{array}$ & Area [ha] & $\%$ \\
\hline 1. & Cropland & 31932.71 & 51.7 \\
\hline 2. & Orchards & 829.58 & 1.3 \\
\hline 3. & $\begin{array}{l}\text { Permanent } \\
\text { meadows }\end{array}$ & 8841.58 & 14.3 \\
\hline 4. & $\begin{array}{l}\text { Permanent } \\
\text { pastures }\end{array}$ & 2351.78 & 3.8 \\
\hline 5. & $\begin{array}{c}\text { Built-up } \\
\text { agricultural land }\end{array}$ & 1688.60 & 2.7 \\
\hline 6. & $\begin{array}{l}\text { Pond and ditch } \\
\text { bottoms }\end{array}$ & 533.31 & 0.9 \\
\hline 7. & Wasteland & 1364.53 & 2.2 \\
\hline \multicolumn{2}{|c|}{ Total land in use } & 47542.09 & 77.0 \\
\hline 8. & Forests & 8344.82 & 13.5 \\
\hline 9. & $\begin{array}{c}\text { Land with tree } \\
\text { stands and shrubs }\end{array}$ & 1458.94 & 2.4 \\
\hline \multicolumn{2}{|c|}{ Total forestland in use } & 9803.76 & 15.9 \\
\hline 10. & Housing grounds & 144.97 & 0.2 \\
\hline 11. & $\begin{array}{c}\text { Industrial } \\
\text { grounds }\end{array}$ & 183.16 & 0.3 \\
\hline 12. & $\begin{array}{l}\text { Other built-up } \\
\text { grounds }\end{array}$ & 323.87 & 0.5 \\
\hline 13. & $\begin{array}{c}\text { Urbanized } \\
\text { grounds without } \\
\text { buildings }\end{array}$ & 77.44 & 0.1 \\
\hline 14. & Leisure grounds & 34.15 & 0.1 \\
\hline 15. & $\begin{array}{l}\text { Transport } \\
\text { grounds }\end{array}$ & 1684.57 & 2.7 \\
\hline 16. & $\begin{array}{l}\text { Surface mining } \\
\text { grounds }\end{array}$ & 35.81 & 0.1 \\
\hline \multicolumn{2}{|c|}{$\begin{array}{l}\text { Total built-up and } \\
\text { urbanized grounds }\end{array}$} & 2483.96 & 4.0 \\
\hline 17. & $\begin{array}{l}\text { Bottoms of } \\
\text { surface water } \\
\text { courses }\end{array}$ & 875.83 & 1.4 \\
\hline 18. & Ecological areas & 959.90 & 1.6 \\
\hline 19. & $\begin{array}{l}\text { Various } \\
\text { grounds }\end{array}$ & 71.84 & 0.1 \\
\hline \multicolumn{2}{|r|}{ Total } & 61737.38 & 100.00 \\
\hline
\end{tabular}

Source: own elaboration

The average level of forest cover amounting to 9803.76 ha $(15.9 \%)$ of the total area of the analysed county is worth noting. Built-up and urbanized grounds occupying an area of 2483.96 ha $(4.0 \%)$ are mainly transport grounds, occupying 1684.57 ha (2.7\%). Bottoms of surface water courses account for 875.83 ha $(1.4 \%)$ of the total area. The percentage of other land in use is insignificant. Ecological areas occupy only 959.90 ha $(1.6 \%)$ of the total area of the county of Łeccna. To sum up, the analysed area is dominated by agricultural land and forestland. As much as $80.3 \%$ of this area is privately owned land.

\section{Conlusion}

Adopting one figure as the index of productivity for cropland, meadows and pastures makes it possible to classify a larger number of villages according to one feature. It makes it possible to group the villages into larger typological units. In addition, groups can be formed based on the index value creating adequate ranges. Moreover, other features can be added in order to extend the characteristics of the analysed area. Thus, the villages can be grouped even better according to similarities. The division of agricultural production space and classification of villages into groups is helpful in making decisions in the area of the widely interpreted land management. The values of productivity index for cropland, meadows and pastures expressed in figures constitute very important information when planning and programming land consolidation and exchange works.

When the calculated ratios and other characteristics describing the spatial structure of the analysed area are applied, such an area can be delimited. Land consolidation works require grouping villages into larger clusters and consolidating over larger areas, e.g. a few villages at the same time. In addition, villages with the best soil conditions can be identified for consolidation in the first place with regard to their large influence on agricultural production. If the villages are in a neighbouring location, likewise in the analysed county, it is advisable to perform consolidation in all such villages simultaneously.

The use of a numeric index also makes it possible to prepare a ranking of villages for consolidation with regard to soil quality. As comprehensive land consolidation and exchange works are a complex process 
covering large areas, it is not possible to consolidate all villages requiring such treatment simultaneously. Therefore, a reasonable solution is identifying villages that need such treatment in the first place. The numeric index of productivity presented in this paper can be used for creating a ranking of soil quality, and then for objective distribution of EU financial grants for post-consolidation management when making decisions on their allocation. The calculated ratios can also be used for economic, spatial or land development planning purposes.

\section{Acknowledgements}

Publication is funded by the Polish National Agency for Academic Exchange under the International Academic Partnerships Programme from the project „Organization of the 9th International Scientific and Technical Conference entitled Environmental Engineering, Photogrammetry, Geoinformatics - Modern Technologies and Development Perspectives".

\section{References}

1. Noga K. Wplyw różnych czynników na zmiany użytkowania gruntów we wsiach górskich. (Effect of various factors on changes in the use of land in mountain villages) National Conference of the Chief Technical Organisation (NOT), Białystok. (1978) In Polish

2. Whitehead G. Economy, Poznań, Wydawnictwo Zysk i S-ka (2001)

3. Matkowska K. Metodologia określania wartości gruntów dla potrzeb kompleksowych prac scaleniowych. (Methods of land valuation for the needs of comprehensive consolidation works) Doctoral dissertation. The Hugo Kołłątaj Agricultural University of Kraków. (2016) In Polish

4. Boisvert, R.N., Schmit, T.M., Regmi, A., Spatial, productivity, and environmental determinants of farmland values. Am. J. Agric. Econ. 79, 1657. http://dx.doi.org/10.2307/ 1244398. (1997)

5. Sills, E.O., Caviglia-Harris, J.L., Evolution of the Amazonian frontier: land values in Rondônia, Brazil. Land Use Policy 26, 5567. http://dx.doi.org/10.1016/j.landusepol. 2007.12.002. (2009)

6. De la Fuente, E.B., Suárez, S.A., Ghersa, C.M., Soybean weed community composition and richness between 1995 and 2003 in the Rolling Pampas (Argentina). Agric.

Ecosyst. Environ. 115, 229-236. http://dx.doi.org/10.1016/j.agee.2006.01.0 09. (2006)

7. Choumert J., Phelinas P., 2015. Determinants of agricultural land values in Argentina. Ecological Economics. 110 (2015) 134-140

8. Van der Putten, W., Ramirez, K., Poesen, J., Lisa, L., Simek, M., Winding, A., Economou-Eliopoulos, M., Opportunities for soil sustainability in Europe. EASAC policy report 36. (2018.)

9. Vejchodska E., Pelucha M., Environmental charges as drivers of soil sealing? The case of the Czech charge for agricultural land loss. Land Use Policy. 87 (2019) 104071 (2019)

10. Ustaoglu E., Perpina Castillo C., JacobsCrisioni C., Lavalle C., Economic evaluation of agricultural land to assess land use changes. Land Use Policy. 56 (2016) 125-146. (2016)

11. Wójcik-Leń, J.; Sobolewska-Mikulska, K.; Sajnóg, N.; Leń, P. The idea of rational management of problematic agricultural areas in the course of land consolidation. Land Use Policy 78, 36-45. (2018)

12. Janus J., Taszakowski J. Spatial differentation of the soil quality in Dabrowski administrative district. Infrastructure and Ecology of Rural Areas. No. 2014/ II (2 (Jun 2014)), pp. 609-622, (2014). In Polish

13. Noszczyk T., Rutkowska A., Hernik J. Determining Changes in Land Use Structure in Matopolska Using Statistical Methods. Polish Journal of Environmental Studies, 26(1), 211-220. DOI: 10.15244/pjoes/64913 (2017)

14. Noszczyk T. Land use change monitoring as a task of local government administration in Poland. Journal of Ecological Engineering, 19(1), 170-176. DOI: 10.12911/22998993/7940. (2018)

15. Leń P. Breakdown of county agricultural space Brzozowski in terms of production value of cropland and grassland. Infrastructure and Ecology of Rural Areas. vol. 12/2010, 2010, pp. 37-44 (2010)

16. Witek T., Górski T. Przyrodnicza Bonitacja Rolniczej Przestrzeni Produkcyjnej w Polsce (Natural classification of soil quality in the agricultural production space in Poland), Wydawnictwa Geologiczne, Warszawa, (1977) In Polish.

17. Dudzińska M. Czynniki determinujace wartość rynkowa gruntu rolnego $i$ wartość 
gruntu $w$ postepowaniu scaleniowym. (Factors determining the market value of agricultural land and the value of land in consolidation proceedings). Acta Scientiarum Polonorum. Vol. 9 (4), 2010, pp.19-28, (2010) In Polish

18. Sobolewska-Mikulska K. Procedury prawno-geodezyjne $w$ gospodarce gruntami na obszarach rolnych (Legal and land surveying procedures in the management of rural land). Warszawa: Oficyna Wydawnicza Politechniki Warszawskiej, pp. 23, (2015) In Polish

19. Hudecová L., Geisse R., Vardžáková M., Turan P., Calculation of land fragmentation. Kartografické listy / Cartographic letters, 24 (1), pp. 12-22. (2016)

20. Leń P. 2018. An algorithm for selecting groups of factors for prioritization of land consolidation in rural areas. Computers and Electronics in Agriculture 144 (2018) 216-221.

DOI: 10.1016/j.compag.2017.12.014 (2018)

21. Leń P., Mika M. Determination of the urgency of undertaking land consolidation works in the villages of the Stawno municipality. Journal of Ecological Engineering. Volume 17, Issue 4, Sept. 2016, 163-169pp. DOI: 10.12911/22998993/64827. (2016)

22. Postek, P. Differences in spatial structure of rural areas of commune of Goraj with regard to size of farms owned by natural persons. In Proceedings of the 17th International Scientific Conference Engineering for Rural Development, Jelgava, Latvia, 23-25 May 2018; pp. 605-610, doi:10.22616/ERDev2018.17.N226. (2018)

23. Strek Z. Differences in spatial structure of agricultural areas in Ksiezpol commune with regard to productivity of cropland and grassland Proceedings of $17^{\text {th }}$ International Scientific Conference Engineering for Rural Development www.tf.llu.lv. ISSN 1691-5976. 23 25.05.2017 Jelgava, Latvia, 2018, 592598, DOI: 10.22616/ERDev2018.17.N223 (2018)

24. Tomic, H.; Mastelic Ivic, S.; Roić, M. Land Consolidation Suitability Ranking of Cadastral Municipalities: InformationBased Decision-Making Using MultiCriteria Analyses of Official Registers' Data. Int. J. Geo-Inform., 7, 87, doi:10.3390/ijgi7030087. (2018)

25. Stręk Ż., Noga K. Method of Delimiting the Spatial Structure of Villages for the
Purposes of Land Consolidation and Exchange. Remote Sens. 11, 1268 (2019) 